\title{
THE EFFECT OF CAREER EXPECTATION, CAREER GUIDANCE, AND WORK MOTIVATION TOWARD WORK READINESS STUDENT
}

\section{PENGARUH EKSPEKTASI KARIR, BIMBINGAN KARIR, DAN MOTIVASI KERJA TERHADAP KESIAPAN KERJA SISWA}

Oleh:

\section{Gifaninda Sofiani}

Accounting Education Study Program Yogyakarta State University

gifanindasofiani20@gmail.com

\author{
Abdullah Taman \\ Lecturer in Accounting Education Study Program Yogyakarta State University \\ abtaman@uny.ac.id
}

\begin{abstract}
This research aims to determine: 1) The effect of Career Expectation toward Work Readiness student, 2) The effect of Career toward Work Readiness student, 3) The effect of Work toward Work Readiness student, 4) The effect of Career Expectation, Career Guidance, and Work Motivation simultaneoulsy toward Work Readiness student. This research is an Ex-post facto study with a quantitative approach, conducted at SMK Negeri 1 Bantul with the subject of student of XII Accounting Grader. The data collection technique used was a questionnaire. Before analyzing the data, a prerequisite test for analysis must be carried out, namely normality test, linearity test, and multicollinearity test. The data analysis technique used in this study is simple regression analysis and multiple regression analysis. The results of this study are: 1) There is a positive and significant influence between Career Expectation and Work Readiness with a value of $\mathrm{r}^{2}{ }_{\mathrm{x} 1 \mathrm{y}}$ 0.153. 2) There is a positive and significant influence between Career Guidance and Work Readiness with a value of $r^{2}{ }_{x 2 y} 0.205$. 3) There is a positive and significant influence between Work Motivation and Work Readiness toward Work Readiness student with $\mathrm{r}_{\mathrm{x} 3 \mathrm{y}}$ 0.124. 4) There is a positive and significant influence between Career Expectation, Career Guidance, and Work Motivation simultaneoulsy toward Work Readiness student with a value of $\mathbf{R}_{(1,2,3)}^{2} 0,283$. So Career Guidance is a variable with the greatest influence among the three independent variables with $r_{x 2 y}^{2} 0.205$ so student can be more active in doing Career Guidance that supports Student toward Work Readiness.
\end{abstract}

Keywords: Work Readiness, Career Expectation, Career Guidance, Work Motivation

\section{Abstrak}

Penelitian ini bertujuan untuk mengetahui:1) Pengaruh Ekspektasi Karir terhadap Kesiapan Kerja Siswa, 2) Pengaruh Bimbingan Karir terhadap Kesiapan Kerja, 3) Pengaruh Motivasi Kerja terhadap Kesiapan Kerja Siswa, 4) Pengaruh Ekspektasi Karir, Bimbingan Karir, dan Motivasi Kerja secara bersama-sama terhadap Kesiapan Kerja Siswa. Penelitian ini adalah penelitian Ex-post facto dengan pendekatan kuantitatif. Penelitian ini dilakukan di SMK Negeri 1 Bantul dengan subjek Siswa Kelas XII Program Keahlian Akuntansi Teknik pengumpulan data yang digunakan adalah angket. Sebelum dilakukan analisis data, maka dilakukan uji prasyarat analisis yaitu uji normalitas, uji linieritas, dan uji multikolinieritas. Teknik analisis data yang digunakan adalah analisis regresi sederhana dan analisis regresi 
ganda.Hasil penelitian ini adalah: 1) Terdapat pengaruh positif dan signifikan antara Ekspektasi karir dengan Kesiapan Kerja Siswa dengan nilai ${ }^{2}{ }_{x y y}$ sebesar 0,153. 2) Terdapat pengaruh positif dan signifikan antara Bimbingan karir dengan Kesiapan Kerja Siswa dengan nilai $r_{x 2 y}^{2}$ sebesar 0,205. 3) Terdapat pengaruh positif dan signifikan antara Motivasi kerja dengan kesiapan kerja Siswa dengan nilai $r_{x 3 y}^{2}$ sebesar 0,124. 4) Terdapat pengaruh positif dan signifikan antara Ekspektasi Karir, Bimbingan Karir, dan Motivasi Kerja secara bersama-sama terhadap Kesiapan Kerja Siswa dengan nilai $R_{(1,2,3)}^{2}$ sebesar 0,283. Jadi Bimbingan karir merupakan variabel dengan pengaruh paling besar diantara ketiga variabel bebas yang diteliti, ditunjukan dengan $r_{x 2 y}^{2}$ sebesar 0,205 sehingga siswa dapat lebih giat dalam melakukan Bimbingan Karir yang mendukung Kesiapan Kerja Siswa.

Kata Kunci: Kesiapan Kerja, Ekspektasi karir, Bimbingan Karir, Motivasi Kerja

\section{INTRODUCTION}

Law Number 20 of 2003 Article 15 concerning the National Education System states that, "Vocational education is secondary education which prepares student primarily to work in certain fields". According to Mager (1996: 2), the purpose of teaching is to release student to be able to work satisfactorily at work and be able to improve their skills during work. Therefore, vocational education has a goal, that is prepare learners in the field of employment and effective participation in the world of work. Vocational School (SMK) is formal education that has a specific teaching method to guide and direct student to become graduates who are ready and professional in the world of work both in the company and develop their own business. The vision of the Development of Vocational High Schools is the formation of individuals and ecosystems of vocational education with character based on mutual cooperation, while the mission are:

1. Realizing strong vocational high school education actors.

2. Realizing vocational high school access that is widespread, equitable and equitable.

3. Realizing quality learning in Vocational High Schools.

4. Realizing strengthening governance and increasing the effectiveness of bureaucracy and public involvement.
If we look at the condition of student who are currently graduates of vocational education, there are still many student who feel they are not ready to work. This creates a discrepancy between the actual conditions and the objectives of vocational education that have been regulated in the law. The data contained in the Badan Pusat Statistik (BPS) shows that the number of workforce in February 2018 was 133,94 million people, up 2,39 million compared to February 2017. From the level of education, the Open Unemployment Rate (TPT) for Vocational High Schools ( Vocational High Schools occupy the highest position among the other levels of education, which is $8,92 \%$. Of the 127,07 million people who worked, amounting to 7, 64 percent were in the underemployed category and 23,83 percent were included in part-time workers. In the past year, half the unemployed and part-time workrforce 0,02 percent and 1,31 percentage points respectively. Student should be ready to enter the workforce after completing vocational education, but in reality they still feel they are not ready to work and do additional things that they consider will increase knowledge and experience by entering college or taking skills guidance. Student have the desire to work in accordance with what they have planned and not often they also think that, if only armed with a certificate of Vocational High School (SMK) alone is not enough to achieve the job position they want. 
Based on preliminary research conducted by researcher on April 25, 2018 at SMK Negeri 1 Bantul, so far Vocational High Schools (SMK) are still seen as less able to support student' experience in finding jobs. The researcher interviewed six student about Work Readiness and data collection to get information on graduate student who worked and continued on to college. From the results of interviews conducted by researcher found several problems regarding the readiness of work of student at Bantul 1 State Vocational School, are as follows:

1. After graduating from Vocational School (SMK) student still want to continue their education to higher education. It is because student feel unsatisfied with the knowledge and experience they have while taking vocational schools. Furthermore, student also want to follow in the footsteps of seniors or alumni who have successfully entered college.

2. If student choose to work after graduating from vocational school, the results or salary to be obtained will be used for college, so they can get an education degree and reach the desired job position. It is shows that student are not fully prepared to work in accordance with their fields, but they work to be able to continue their education.

In addition to the problems regarding Work Readiness of student, researcher also get the data about information on alumni who work as well as those who go on to college. Data shows that student in the accounting program for the 2015/2016 academic year have 39 students out of 133 student or around $30 \%$ of student who continue their education to official and tertiary education institutions, both public and private universities and the remaining 133 participants student or $70 \%$ continue to work, have not worked, opened a business, and married. This shows that there are still quite a lot of student who are not ready to enter the workforce and choose to continue their education.

Harjono (1990: 23) argues, the readiness of student to enter the working world is everything that should be prepared to implement something to achieve a goal, there are several factors that affect the job readiness of learners are, motivation of work, Capacity of work, Capacity of adapt to the environment, the ability to adapt to work, the ability to communicate, information about the world of work, the reception of job prospects, opportunities to get employment opportunitie, and the discussion of work done in the world of work. Work Readiness is the condition of someone who is ready about a matter which includes physical, mental, experience, will, and ability maturity in activities to produce something desired.

One of the factors that influence student' Work Readiness is Career Expectation. According to Victor (in Siagian, 2011: 292), expectations can influence individuals in determining actions to be taken to achieve a person's goals or success, including estimates of the various events that will be faced. The expectation of student about Career Expectation indirectly affect the way of learning and how to prepare student to enter the world of career expected by student.

Another factor affecting job readiness namely career guidance, understanding of vocational guidance and one aspect of the guidance that directs a person to work with a happy and comfortable in the work according to the abilities, interests and the situation himself. Another factor affecting job readiness namely career guidance, understanding of vocational guidance and one aspect of the guidance that directs a person to work with a happy and comfortable in the work according to the abilities, interests and the situation himself.

According to Winkel (2005: 114): 
" Career Guidance is guidance in preparing to face the world of work, in choosing jobs or positions and certain proceses and equipping oneself to be ready to undergo work and be able to adjust to various job demands".

Whereas according to Marsudi (2003: 113)

"Career Guidance is a device or more precisely a systematic program, process, technique, and service that aims to assist individuals in understanding and acting on the basis of the introduction of opportunities in work, education, and leisure, and developing decisionmaking skills so that individuals can create and manage their career development ".

From the definition above, it can be concluded that Work Readiness is a method carried out by someone to prepare themselves to enter the workforce. Based on the description above, researcher are interested in conducting research on the factors that influence the Readiness of Work of Student. These factors are Career Expectation, Career Guidance, and Work Motivation. Thus, the title of this research is "The Effect of Career Expectation, Work Guidance, and Work Motivation Toward Work Readiness Student Of XII Accounting Grader At SMK Negeri 1 Bantul, Academic Year Of 2018/2019".

\section{RESEARCH METHOD \\ Research Design}

This research is quantitative approach, this is because many use the figures, from the collection of data, interpretation of data, and the appearance of the results (Suharsimi Arikunto, 2010: 27). The design of this research is causal comparative, because this research is intended to determine the causes due to the effect of Career Expectation, Career Guidance, and Work Motivation on Work
Readiness of Student in the Accounting Skills Program. This research is an ex post facto study, this research focuses on the variables that occurred before the research was conducted.

\section{Place and Times of Research}

This research was conducted at SMK Negeri 1 Bantul, located on Jl. Parangtritis Km 11 Sabdodadi Bantul Yogyakarta. This research was conducted in class XII Accounting Grader Academic Year of 2018/2019. Implementation of research in January 2018. The researcher conducted an initial survey at SMK Negeri 1 Bantul on April 25, 2018.

\section{Population and Sample}

The population in this research were all student of class XII of the Accounting Skills Program of SMK N 1 Bantul Academic Year of 2018/2019, which amounted to 127 student.

Table 1. Research Population

\begin{tabular}{|c|c|c|}
\hline No & Class & Total \\
\hline 1. & XII Accounting 1 & 32 \\
\hline 2. & XII Accounting 2 & 32 \\
\hline 3. & XII Accounting 3 & 31 \\
\hline 4. & XII Accounting 4 & 32 \\
\hline & Total & 127 \\
\hline
\end{tabular}

Based on the existing tables in the book Sugiyono (2003: 62) the determination of the number of samples with a population of 127 students with an error rate of $5 \%$ is as many as 95 students.

Table 2. Distribution of Research Sample Number

\begin{tabular}{|c|c|c|}
\hline No & Class & Total \\
\hline 1. & XII Accounting 1 & 24 \\
\hline 2. & XII Accounting 2 & 24 \\
\hline 3. & XII Accounting 3 & 23 \\
\hline 4. & XII Accounting 4 & 24 \\
\hline & Total & 95 \\
\hline
\end{tabular}

Data Collection Technique 
The data collection technique used in this research was a questionnaire (questionnaire). In this research the questionnaire is a closed statement and to obtain data is done by distributing questionnaires directly to respondents or student. This data collection method is used to obtain data on Student Work Readiness, Career Expectation, Career Guidance, and Work Motivation.

\section{Research Instrument}

According to Sugiyono (2017: 92), the research instrument is used to measure the value of the variable under study. The questionnaire used in this study was a closed questionnaire. Questionnaires are equipped with alternative answers so that respondents can choose one of the available answers. The following are the steps for preparing research instruments are:

1. Make a quetionnaire grid

Making questionnaires is used to obtain data on Career Expectation (X1), Career Guidance (X2), Work Motivation (X3), and Work Readiness (Y).

2. Arrange the statement items

The statement items are in the form of positive statements that support research ideas and negative statements that do not support research ideas. The statement also has four alternative choices, they are Selalu (SL), Sering (SR), Kadang-kadang (KD), and Tidak Pernah (TP); also Sangat Setuju (SS), Setuju (S), Tidak Setuju (TS), and Sangat Tidak Setuju (STS).

3. Scoring

Making instrument scores using a modified Likert scale. Sugiyono (2017: 93), defines the likert function as "used to measure student' attitudes, opinions and perceptions". Each research statement is given four choices of answers, they are Selalu (SL),
Sering (SR), Kadang-kadang (KD), and Tidak Pernah (TP); also Sangat Setuju (SS), Setuju (S), Tidak Setuju (TS), and Sangat Tidak Setuju (STS), this aims to express the firmness of the respondent's answer. The score for each positive statement $(+)$ is $4-1$, the score for negative statement (-) is 1-4

\section{Instrument Trial Testing}

The instrument trial testing was conducted to determine the level of validity and the reliability of a research instrument. All instruments used in the study must be tested for validity and reliability before the instrument can be used as a tool to obtain research data. According to Suharsimi (2005: 161) research subjects were used as test subjects and at the same time the subject of research. Instrument testing is done by taking samples randomly in the study population conducted at SMK Negeri 1 Bantul, it is to make it easier for researchers to find similarities in the characteristics of objects and subjects in the research trials with real research. The subjects for this research trial were 32 student of class XII of the Accounting expertise program at SMK Negeri 1 Bantul which were randomly selected.

\section{Data Analysis Technique}

a. Analysis of Requirement Test

1) Normality Test

The normality test serves to find out the data obtained from each variable with normal distribution or not. To test the data normality of each variable can be done by non-parametric test-One Sample Kolmogrov Smirnov Test on regression models using the help of statistical applications. If the value of sig regression model > 0.05, the data is normally distributed. Conversely, if the 
value of sig $<0.05$, the data is not normally distributed.

2) Linearity Test

The linear test serves to determine whether there is a relationship between each independent variable $(\mathrm{X})$ and the dependent variable. If the $\mathrm{F}_{\text {count }}$ is equal to or smaller than $\mathrm{F}_{\text {table }}$ at the $5 \%$ siginality level, the relationship between the independent variables is linear and vice versa if the $F_{\text {count }}$ is greater than $F_{\text {table }}$ at the $5 \%$ significance level then the relationship between the independent variables is declared not linear.

3) Multicollinearity Test

The multicollinearity test is used to test assumptions in multiple regression analysis. Multicollinearity test aims to determine whether or not there is multicolianearity between independent variables. If there are multicollinearity among independent variables, then the multiple correlation test cannot be continued, on the contrary if there is no multicollinearity between independent variables, then multiple correlation tests can be continued

b. Hypothesis Test

1) Simple Regression Analysis

Simple regression analysis technique serves to test whether there is influence between one independent variable individually and the dependent variable.
2) Multiple Regression Analysis

Multiple regression analysis functions to determine the effect of all independent variables simultaneoulsy on the dependent variable.

\section{RESULT AND DISCUSSION}

Analysis of Requirement Test

a. Normality Test

The results of the normality test of this study are:

Table 3. Summary of the Result of Normality Test

\begin{tabular}{|c|c|}
\hline $\mathrm{N}$ & 95 \\
\hline Sign.count & 0,200 \\
\hline Sign. & 0,05 \\
\hline Condition & Sign.count $>$ Sign \\
\hline Conclusion & Normal \\
\hline
\end{tabular}

Based on the data in table 3, it can be seen that the Sign.count is greater than the Sign. This proves that all research variable data are normally distributed.

\section{b. Linearity Test \\ The results of the linearity test in this study are:}

Table 4. Summary oh the Result of Linearity Test

\begin{tabular}{|c|c|c|c|c|}
\hline $\begin{array}{c}\text { Vari } \\
\text { able }\end{array}$ & $\mathbf{F}_{\text {count }}$ & $\mathbf{F}_{\text {table }}$ & Condition & $\begin{array}{l}\text { Concl } \\
\text { usion }\end{array}$ \\
\hline $\mathrm{X}_{1}-\mathrm{Y}$ & 0,964 & 1,729 & $\mathrm{~F}_{\text {count }}<\mathrm{F}_{\text {table }}$ & Linier \\
\hline $\mathrm{X}_{2}-\mathrm{Y}$ & 0,751 & 1,777 & $\mathrm{~F}_{\text {count }}<\mathrm{F}_{\text {table }}$ & Linier \\
\hline $\mathrm{X}_{3}-\mathrm{Y}$ & 0,953 & 1,729 & $\mathrm{~F}_{\text {count }}<\mathrm{F}_{\text {table }}$ & Linier \\
\hline
\end{tabular}

From table 4 above, it is known that $F_{\text {count }}$ is smaller than $F_{\text {table }}$ for all relationships between independent variables, it is said that all relationships between independent variables in this study are linear.

c. Multicollinearity Test

Based on the multicollinearity test using the help of statistical applications, the results obtained are: 
Table 5. Summary of the Result of Multicollinearity Test

\begin{tabular}{|c|c|c|c|c|}
\hline Variable & $\mathbf{X}_{1}$ & $\mathbf{X}_{2}$ & $\mathbf{X}_{3}$ & $\begin{array}{l}\text { Concl } \\
\text { usion }\end{array}$ \\
\hline Career & 1 & 0,45 & 0,21 & \multirow{6}{*}{$\begin{array}{l}\text { There } \\
\text { is no } \\
\text { multi- } \\
\text { colli- } \\
\text { neari- } \\
\text { ty }\end{array}$} \\
\hline $\begin{array}{l}\text { Expectation } \\
\left(\mathrm{X}_{1}\right)\end{array}$ & & 2 & 0 & \\
\hline Career & 0,45 & 1 & 0,35 & \\
\hline $\begin{array}{l}\text { Guidance } \\
\left(\mathrm{X}_{2}\right)\end{array}$ & 2 & & 8 & \\
\hline Work & 0,21 & 0,35 & 1 & \\
\hline $\begin{array}{l}\text { Motivation } \\
\left(\mathrm{X}_{3}\right)\end{array}$ & 0 & 8 & & \\
\hline
\end{tabular}

Table 5 above shows that the magnitude of the correlation between independent variables is smaller than 0.800 . Its means that there is no multicollinearity between independent variables and analysis can continue.

\section{Hypothesis Test}

a. First Hypothesis Testing

A summary of the simple regression results can be seen in the following table:

Table 6. Summary of the Result of Simple Regression Analysis ( $\left.\mathrm{X}_{1}-\mathrm{Y}\right)$

\begin{tabular}{|l|c|}
\hline \multicolumn{1}{|c|}{ Variable } & Coefficient \\
\hline $\mathrm{X}_{1}$ & 0,469 \\
\hline Constanta & 31,730 \\
\hline $\mathrm{r}_{\mathrm{x} 1 \mathrm{y}}$ & 0,391 \\
\hline $\mathrm{r}_{\mathrm{x} 1 \mathrm{y}}^{2}$ & 0,153 \\
\hline $\mathrm{t}_{\text {count }}$ & 4,094 \\
\hline $\mathrm{t}_{\text {table }}$ & 1,986 \\
\hline Sign & 0,000 \\
\hline
\end{tabular}

Based on the results of the analysis, it can be seen that the correlation coefficient $\mathrm{X} 1$ against $\mathrm{Y}$ shows $r_{x 1 y}$ of 0.391 . The correlation coefficient is positive so that it can be concluded that Career Expectation have a positive relationship with Work Readiness. It shows that the coefficient of determination $\mathrm{X}_{1}$ to $\mathrm{Y}$ shows $r_{x 1 y}^{2}$ of 0.153 . This shows that, Career Expectation affect Work Readiness by $15.3 \%$, while $84.7 \%$ is influenced by other factors. the regression line equation can be expressed in the equation as follows: $\mathrm{Y}=0,469 \mathrm{X}_{1}+31,730$

This equation shows that the regression coefficient value $X_{1}$ is positive at 0.469 , which means that if the Career Expectation value $\left(\mathrm{X}_{1}\right)$ increases by 1 unit then the value of Work Readiness (Y) will increase by 0.569 units. The significance test used is the $t$ test. Based on the results of the $t$ test obtained tcount of 4.094. When compared with the ttable value of 1.986 at a significance level of $5 \%$, the tcount $>$ ttable, so it can be concluded that there is a positive and significant influence between Career Expectations $\left(\mathrm{X}_{1}\right)$ on Work Readiness (Y) Student.

b. Second Hypothesis Testing

A summary of the simple regression results can be seen in the following table:

Table 7. Summary of the Result of Simple Regression Analysis $\left(\mathbf{X}_{2-}\right.$ Y)

\begin{tabular}{|l|c|}
\hline \multicolumn{1}{|c|}{ Variable } & Coefficient \\
\hline $\mathrm{X}_{2}$ & 0,545 \\
\hline Constanta & 29,843 \\
\hline $\mathrm{r}_{\mathrm{x} 2 \mathrm{y}}$ & 0,453 \\
\hline $\mathrm{r}_{\mathrm{x} 2 \mathrm{y}}$ & 0,205 \\
\hline $\mathrm{t}_{\text {count }}$ & 4,094 \\
\hline $\mathrm{t}_{\text {table }}$ & 1,986 \\
\hline Sign & 0,000 \\
\hline
\end{tabular}

Based on the results of the analysis using the help of statistical applications, it can be seen that the correlation coefficient $\mathrm{X}_{2}$ against $\mathrm{Y}$ shows $r_{x 2 y}$ of 0.453 . The correlation coefficient is positive so that it can be concluded that Career Guidance has a positive relationship with Work 
Readiness. The coefficient of determination $\mathrm{X}_{2}$ to $\mathrm{Y}$ shows $\mathrm{r}_{\mathrm{x} 2 \mathrm{y}}^{2}$ of 0.205 . This shows that Career Guidance affects Work Readiness by $20.5 \%$, while $79.5 \%$ is influenced by other factors. the regression line equation can be expressed in the equation as follows: $\mathrm{Y}=0,545 \mathrm{X}_{2}+$ 29,843

The equation shows that the regression coefficient value $\mathrm{X}_{2}$ is positive at 0.545 , which means that if the Career Guidance value $\left(\mathrm{X}_{2}\right)$ increases by 1 unit then the value of Work Readiness (Y) will increase by 0.545 units. The significance test used is the $t$ test. Based on the results of the $t$ test obtained tcount of 4.094 . When compared with the table value of 1.986 at a significance level of $5 \%$, the tcount $>$ ttable, so it can be concluded that there is a positive and significant influence between Career Guidance $\left(\mathrm{X}_{2}\right)$ on Work Readiness (Y) Readiness Student.

c. Third Hypothesis Testing

A summary of the simple regression results can be seen in the following table:

Table 8. Summary of the Result of Simple Regression Analysis ( $\mathrm{X}_{3}$ Y)

\begin{tabular}{|l|c|}
\hline \multicolumn{1}{|c|}{ Variable } & Coefficient \\
\hline $\mathrm{X}_{3}$ & 0,374 \\
\hline Constanta & 39,567 \\
\hline $\mathrm{r}_{\mathrm{x} 3 \mathrm{y}}$ & 0,353 \\
\hline $\mathrm{r}^{2} \mathrm{x} 3 \mathrm{y}$ & 0,124 \\
\hline $\mathrm{T}_{\text {count }}$ & 3,636 \\
\hline $\mathrm{t}_{\text {table }}$ & 1,986 \\
\hline Sign & 0,000 \\
\hline
\end{tabular}

Based on the results of the analysis using the help of statistical applications, it can be seen that the correlation coefficient $\mathrm{X}_{3}$ against $\mathrm{Y}$ shows $r_{x 3 y}$ of 0.353 . The correlation coefficient is positive so it can be concluded that Work Motivation has a positive relationship with Work Readiness. The coefficient of determination $\mathrm{X}_{3}$ to $\mathrm{Y}$ shows $\mathrm{r}^{2}$ x3y of 0.124 . This shows that Work Motivation affects Work Readiness by $12.4 \%$, while $87.6 \%$ is influenced by other factors. the regression line equation can be expressed in the equation as follows: $\mathrm{Y}=0,374 \mathrm{X}_{3}+$ 39,567

This equation shows that the regression coefficient value $\mathrm{X}_{3}$ is positive at 0.374 , which means that if the Work Motivation value $\left(\mathrm{X}_{3}\right)$ increases by 1 unit, the value of Work Readiness (Y) will increase by 0.374 units. The significance test used is the $t$ test. Based on the results of the t test obtained tcount of 3.636. When compared with the ttable value of 1.986 at a significance level of $5 \%$, the $t_{\text {count }}>t_{\text {table, }}$ so it can be concluded that there is a positive and significant influence between Work Motivation $\left(\mathrm{X}_{3}\right)$ on Work Readiness (Y) Student.

d. Fourth Hypothesis Testing

A summary of the simple regression results can be seen in the following table:

Table 9. Summary of Multiple Regression Results $\left(\mathbf{X}_{1}, \mathbf{X}_{2}, \mathbf{X}_{3}\right.$ Y)

\begin{tabular}{|l|c|}
\hline \multicolumn{1}{|c|}{ Variable } & Coefficient \\
\hline $\mathrm{X}_{1}$ & 0,270 \\
\hline $\mathrm{X}_{2}$ & 0,330 \\
\hline $\mathrm{X}_{3}$ & 0,212 \\
\hline Constanta & 18,141 \\
\hline $\mathrm{R}$ & 0,532 \\
\hline $\mathrm{R}^{2}$ & 0,283 \\
\hline $\mathrm{F}_{\text {count }}$ & 11,961 \\
\hline $\mathrm{F}_{\text {table }}$ & 2,706 \\
\hline Sign & 0,000 \\
\hline
\end{tabular}

Based on the results of the analysis using the help of statistical 
applications, it can be seen that the correlation coefficients $\mathrm{X}_{1}, \mathrm{X}_{2}$, and $\mathrm{X}_{3}$ against $\mathrm{Y} \mathrm{R}_{\mathrm{y}(1,2,3) \text { show a value }}$ of 0.532 . The correlation coefficient is positive so that it can be concluded that Career Expectations, Career Guidance, and Work Motivation simultaneoulsy have a positive relationship with Work Readiness. Based on table 9, it shows that the coefficient of determination $\mathrm{R}^{2}$ shows 0.283 . This shows that Career Expectations, Career Guidance, and Work Motivation jointly affect Work Readiness by $28.3 \%$, while $71.7 \%$ is influenced by other factors. the regression line equation can be expressed in the equation as follows: $\mathrm{Y}=18,141+0,270 \mathrm{X}_{1}+$ $0,330 X_{2}+0,212 X_{3}$

The equation shows that the regression coefficient value $X_{1}$ is positive at 0.270 which means that if the Career Expectation value $\left(\mathrm{X}_{1}\right)$ increases by 1 unit then the Work Readiness (Y) value will increase by 0.270 units assuming $\mathrm{X}_{2}$ and $\mathrm{X}_{3}$ remain. $\mathrm{X}_{2}$ regression coefficient is positive for 0.330 which means that if the Career Guidance value $\left(\mathrm{X}_{2}\right)$ increases by 1 unit then the Work Readiness value (Y) will increase by 0.330 units assuming $X_{1}$ and $X_{3}$ remain. $X_{3}$ regression coefficient is positive at 0.212 which means that if the Work Motivation value $\left(\mathrm{X}_{3}\right)$ increases by 1 unit then the Work Readiness (Y) value will increase by 0.212 units assuming $X_{1}$ and $X_{2}$ remain. Based on the results of the $\mathrm{F}$ test obtained Fcount of 11,961. When compared with the Ftable value of 2.706 at the significance level of $5 \%$, the value of $F_{\text {coun }}>F_{\text {table }}$, so it can be concluded that there is a positive and significant influence between
Job Expectation $\left(\mathrm{X}_{1}\right)$, Career Guidance $\left(\mathrm{X}_{2}\right)$, and Work Motivation $\left(\mathrm{X}_{3}\right)$ simultaneoulsy towards Work Readiness (Y) Student of XII Accounting Grader at SMK Negeri 1 Bantul Academic Year of 2018/2019.

e. Relative Contribution (RC) and Effective Contribution (EC)

Based on the results of multiple regression analysis, it can be seen that Relative Contribution (RC) and Effective Contribution (EC) of each independent variable (Career Expectations, Career Guidance, and Work Motivation) on the dependent variable (Work Readiness). The magnitude of the $\mathrm{RC}$ and $\mathrm{EC}$ in this study can be seen in the following table:

\begin{tabular}{|l|c|c|}
\hline Variable & $\begin{array}{l}\text { Relative } \\
\text { Contribution } \\
(\boldsymbol{\%})\end{array}$ & $\begin{array}{l}\text { Effective } \\
\text { Contibution } \\
(\boldsymbol{\%})\end{array}$ \\
\hline $\mathrm{X}_{1}$ & 35,91 & 10,16 \\
\hline $\mathrm{X}_{2}$ & 40,97 & 11,59 \\
\hline $\mathrm{X}_{3}$ & 23,13 & 6,54 \\
\hline Total & 100 & 28,3 \\
\hline
\end{tabular}

Based on the results of the analysis listed in table 26, it can be seen that Career Expectation provide a relative contribution of $35,91 \%$, Career Guidance provides a relative contribution of $40,97 \%$, and Work Motivation provides a relative contribution of $23,13 \%$. The coefficient of determination is 0,283 , the coefficient of determination shows the amount of effective contribution from the three independent variables on the dependent variable. Effective contributions of each variable are Career Expectations of 10,16\%, Career Guidance $11,59 \%$, and Work Motivation of $6,54 \%$. Total effective contribution of $28,3 \%$, which means that Career Expectations, Career 
Guidance, and Work Motivation simultaneoulsy provide an effective contribution of $28,3 \%$ to Work Readiness, while $71,7 \%$ is given by other variables not discussed. in this research.

\section{Discussion of Research Result}

a. Effect of Career Expectations toward Work Readiness.

The results of this study indicate a positive and significant influence between Career Expectation variables on the Work Readiness variable indicated by the value $r_{x 1 y}$ of $0.391 ; r^{2}$ x1y for 0.153 ; and $t_{\text {count }}$ 4.904> t table 1.986. Thus it can be concluded that the better the Career Expectations $\left(\mathrm{X}_{1}\right)$ of students, the higher the Work Readiness (Y) of class XII students of accounting skills program at SMK N 1 Bantul. Career Expectations $\left(\mathrm{X}_{1}\right)$ are knowledge about a job that exists and can be created with capital knowledge and skills possessed by students (Krisnawan: 2013). The results of this study are in line with the opinion of Akhmad Kardimin (2004: 2-3) that one of the factors that influence Work Readiness is knowledge of a work or information in the workforce.

This research is also in line with research conducted by I Made Sirsa, et al. (2013) entitled "Contribution of Career Expectations, Work Motivation and Industrial Work Experience to Work Readiness of Class XII Students of State Vocational School 2 Seririt" shows that there is a significant relationship between Career Expectations (X1) on Work Readiness (Y) at Seririt N 2 Vocational School . With the regression line equation $\mathrm{Y}=$ $31,690+0,640 X_{1}$, with significance $0,000<0,05$ and value of $F_{\text {count }} 30,964$, so Career Expectations have a significant correlation with the Job Performance. Based on the results of the research and opinions it can be concluded that the higher the Career Expectations, the higher the Work Readiness of Students will be.

b. Effect of Career Guidance on Work Readiness.

The results of this research indicate a positive and significant influence between Career Guidance variables on the Work Readiness variable which is indicated by the value of $r_{x 2 y}$ of 0.453 ; $\mathrm{r}^{2}{ }_{\mathrm{x} 2 \mathrm{y}}$ for 0.205 ; and $\mathrm{t}_{\text {count }} 4.904>\mathrm{t}_{\text {table }}$ 1.986. Thus it can be concluded that the better Career Guidance $\left(\mathrm{X}_{2}\right)$ students, the higher the Work Readiness (Y) of class XII students of accounting expertise program at SMK N 1 Bantul. According to Bambang Ismaya (2015: 84) Career Guidance $\left(X_{2}\right)$ is an important thing besides formal guidance in school, Work Guidance is the final process that students take after completing their education. Student need guidance, direction, and learning in choosing jobs, so students get jobs according to their characteristics. The results of this study are in harmony with the opinion of Bambang Ismaya (2005: 85) that one of the goals of Career Guidance that affects Work Readiness is to have knowledge about the world of work and work information that supports the maturity of work competencies.

This research is also in line with the research conducted by Elisabet Tatik W (2007) entitled "Industrial Practice Relations, Career Guidance and Learning Achievement with Student Work Mental Readiness shows that there is a positive relationship between Career Guidance $\left(\mathrm{X}_{2}\right)$ on Work Readiness (Y). With $\mathrm{p}=0.004<\mathrm{a}$ $(0,05)$, then Career Guidance has a positive relationship to Workability. 
Based on the results of the research and opinion, it can be concluded that the higher the Career Guidance, the higher the Work Readiness of Students will be.

c. Effect of Work Motivation on Work Readiness.

The results of this study indicate a positive and significant influence between the Work Motivation variable on the Work Readiness variable indicated by the value of $r_{x 3 y}$ of 0.352 ; $r^{2} \times 3 y$ for 0.124 ; and $t_{\text {count }} 3.636>t_{\text {table }}$ 1.986. Thus it can be concluded that the better the Work Motivation $\left(\mathrm{X}_{3}\right)$ of students, the higher the Work Readiness (Y) of class XII students of accounting skills program at SMK N 1 Bantul. Work Motivation $\left(\mathrm{X}_{3}\right)$ is a drive that comes from self-awareness to achieve success in a job (Dariyo, 2003). The results of this study are in line with Berzberg's opinion that one of the factors that influence Work Readiness is the success achieved from recognition from others.

This research is also in line with the research conducted by Emi Prabawati (2012) entitled "The Effect of Motivation Entering the World of Work and Experience of Industrial Work Practices towards Work Readiness of Class XII Students of Accounting Skills Program in SMK N 1 Tempel. a positive and significant relationship between Work Motivation $\left(\mathrm{X}_{3}\right)$ on Work Readiness (Y) Class XII Student of SMK N 1 Tempel Academic Year of 2011/2012. With a calculated value of 0.448 ; and $t_{\text {count }}$ 5.133> t table 1.658, then Work Motivation has a positive and significant correlation to the Workability. Based on the results of the research and opinions it can be concluded that the higher the Work
Motivation, the higher the Work Readiness of Students will be.

d. Effect of Career Expectations, Career Guidance, and Work Motivation simultaneoulsy toward Work Readiness.

The results of the study after analysis simultaneoulsy between the three independent variables with one dependent variable obtained positive and significant influence between Career Expectations, Career Guidance, and Work Motivation simultaneoulsy on Work Readiness, which is indicated by the value of $\mathrm{R}_{(1,2,3)}$ of 0,$532 ; \mathrm{R}^{2}{ }_{(1,2,3)}$ of 0,$283 ; \mathrm{F}$ count is 11,961; Ftable of 2,706. This shows that, R2 $(1,2,3)$ of 0,283 shows $28,3 \%$ of Student Work Readiness is influenced by Career Expectations, Career Guidance, and Work Motivation, while the remaining $71,7 \%$ is influenced by other factors not discussed in this research.

These results are in accordance with the theory explained by Goerge J. Mooully that one of the factors that can affect student Work Readiness is psychological factors, to be able to do certain work properly, a person must have good motivation. In addition, this study is also in line with the opinions expressed by Akhmad Kardimin (2004: 2-3), there are two factors that influence student Work Readiness, namely the first internal factors consists of physical and mental maturity, pressure, creativity, interest, talent, knowledge, independence, intelligence, and motivation. Both external factors include Career Guidance, workforce information, work experience, and family environmentkarir, information on the world of work, 
work experience, and family environment.Based on the theory and research that has been done, it can be concluded that Career Expectations, Career Guidance and Work Motivation jointly influence students' Work Readiness positively.

\section{CONCLUSION AND SUGGESTION Conclusion}

a. There is a positive and significant influence between Career Expectations on the Work Readiness Student of XII Accounting Grader at SMK Negeri 1 Bantul Academic Year of 2018/2019 which is indicated by the value $r_{x 1 y}$ of 0,$391 ; r^{2}{ }_{x 1 y}$ for 0,$153 ; t_{\text {count }}$ is 4,094 ; $t_{\text {table }}$ equal to 1,986 at the significance level of $5 \%$ and the regression line equation $\mathrm{Y}=0,469 \mathrm{X}_{1}+31,730$.

b. There is a positive and significant influence between Career Guidance on the Work Readiness Student of XII Accounting Grader at SMK Negeri 1 Bantul Academic Year of 2018/2019 which is indicated by the value $r_{x 2 y}$ of 0,$453 ; r^{2}{ }^{2}$ y for 0,$205 ; t_{\text {count }}$ is 4,$094 ; t_{\text {table }}$ is 1,986 at the significance level of $5 \%$ and the regression line equation $\mathrm{Y}=$ $0,545 \mathrm{X}_{2}+29,843$.

c. There is a positive and significant influence between Work Motivation on the Work Readiness Student of XII Accounting Grader at SMK Negeri 1 Bantul Academic Year of 2018/2019 which is indicated by the value $r_{x 3 y}$ of 0,$353 ; r^{2}{ }_{x 3 y}$ for 0,$124 ; t_{\text {count }}$ equal to 3,$636 ; t_{\text {table }}$ equal to 1,986 at the significance level of $5 \%$ and the regression line equation $\mathrm{Y}=0,374 \mathrm{X}_{3}+$ $39,567$.

d. There are a positive and significant influence between Career Expectations, Career Guidance, and Work Motivation simultaneoulsy toward the Work Readiness Student of XII Accounting Grader at SMK Negeri 1 Bantul Academic Year of 2018/2019 which is indicated by the $\mathrm{R}_{(1,2,3)}$ equal to 0.532 ; $\mathrm{R}^{2}(1,2,3)$ of 0,$283 ; \mathrm{F}_{\text {count }}$ is 11,$961 ; \mathrm{F}_{\text {table }}$ of 2,706. at the $5 \%$ significance level and the regression line equation $\mathrm{Y}=$ $18,141+0,270 X_{1}+0,330 X_{2}+0,212$ $\mathrm{X}_{3}$

\section{Suggestion}

a. For School

Based on the research questionnaire Career Expectations, indicators have a positive view of the world of work included in the low category. Schools are expected to be able to provide more knowledge about jobs or careers that will be undertaken by students after graduating from vocational school through information on the world of work or the job market and providing facilities in the search for career knowledge and information from both teachers and other parties, so students have good Career Expectations and high.

b. For Teacher

Based on the Career Guidance research questionnaire, indicators have the ability to broaden world knowledge including in the low category. Therefore teachers are expected to develop Career Guidance methods such as role playing methods and job training for students so that students are able to expand their knowledge and experience in the world of work. In addition, teachers (especially Guidance and Counseling teachers) are also expected to be able to facilitate students in providing information on career or work opportunities and good future planning information.

c. For Student

Based on the research questionnaire Work Motivation, indicators have motivation or motivation from the environment included in the low category. Students are expected to collaborate with the environment such 
as friends, parents, and alumni to find information about the world of work for better student work readiness. This can be done by being selective in choosing students' social environments. The selection of a good and supportive environment will selectively support the Work Satisfaction of Class XII Students in the Accounting Skills Program of SMK Negeri 1 Bantul Academic Year 2018/2019.

d. For futher researcher

This research provides information on Career Expectation factors, Career Guidance, and Work Motivation towards Work Readiness Student of XII Accounting Grader at SMK Negeri 1 Bantul Academic Year of 2018/2019. Effective Contribution given amounted to $28.3 \%$. These results indicate that Student Work Readiness is not only influenced by the three variables discussed in this study. Therefore, it is possible for future researchers to conduct research on other variables related to Student Work Readiness.

\section{REFERENCES}

Arikunto, S. (2010). Prosedur penelitian: Suatu Pendekatan Praktik Edisi Revisi. Jakarta: Rineka Cipta.

Ali Muhson. (2015). Modul Pelatihan SPSS. Yogyakarta: FE UNY

Amundson, N.E., Bowlsbey J.H., Niles, S.G. (2016). Elemen-Elemen Penting Dalam Konseling Karier. Yogyakarta: Pustaka Pelajar.

Badan Pusat Statistik. (2018). Tingkat pengangguran Terbuka di Indonesia tahun 2018.

Diambil dari: (http://www.bps.go.id/pressrelease/ 2018/05/07/1484/februari-2018-- tingkat-pengangguran-terbuka-tpt.html), pada tanggal 26 Juli 2018.

Badan Pengembangan dan Pembinaan Bahasa. Kamus Besar Bahasa Indonesia. Diambil dari: (https://kbbi.kemendikbud.go.id), pada tanggal 18 Desember 2018.

Dariyo, A. (2003). Psikologi Perkembangan Dewasa Muda. Jakarta: PT Grasindo. Djemari Mardapi. (2008). Teknik Penyusunan Instrumen Tes dan Nontes. Yogyakarta: Mitra Cendekia Offset.

Ismaya, B. (2015). Bimbingan dan Konseling: Studi, Karier, dan Keluarga. Bandung: PT Refika Aditama.

Kardimin, A. (2004). Strategi Melamar Kerja dan Bimbingan Karier. Yogyakarta: Pustaka Pelajar.

Kementerian Pendidikan dan Kebudayaan. (2018). Kamus Besar Bahasa Indonesia. Diambil dari: (https://kbbi.kemendikbud.go.id/)

Krisnawan, Candiasa, \& Sunu. (2013). Kontribusi Ekspektasi Karir, Motivasi Belajar Siswa, dan Kualitas Sarana Laboratorium Terhadap Kualitas Pelaksanaan Pembelajaran Praktik. E-Journal: Universitas Pendidikan Ganesha.

Kusumastuti, F. (2018). The Influences Of On The Job Training, Productive Subject Achievement, Social Environment And Motivation To Work Toward The Readiness Of Entering Job Market Of Student Clas XII Accounting SMK N 2 Magelang Academic Year Of 2017/2018. 
Undergraduate Thesis. Yogyakarta State University.

Mager, R.F. \& Beach, K.M. (1996). Mengembangkan Pengajaran Kejuruan. Bandung: Penerbit ITB 1996.

Mangkuprawira, S. (2003). Manajemen Sumber Daya Manusia Strategik. Jakarta Selatan: Ghalia Indonesia

Misbahudin \& Hasan, Iqbal. (2014). Analisis Data Penelitian Dengan Statistik. Jakarta: PT Bumi Aksara.

M. Iqbal Hasan. (2005). Pokok-Pokok Materi Statistik 2. Jakarta: PT Bumi Aksara
Sardiman, A.M. (2007). Interaksi dan Motivasi Belajar-Mengajar. Jakarta: PT Raja Grafindo Persada

Setiawan, Y. (2013). Visi, Misi, dan Tujuan Ekolah Menengah Kejuruan. Diambil pada tanggal 6 Juli 2018, dari https://psmk.kemdikbud.go.id.

Siagian, S.P. (2002). Teori Motivasi dan Aplikasinya. Jakarta: PT Rineka Cipta.

(2008). Manajemen Sumber Daya Manusia. Jakarta: PT Bumi Aksara 